\title{
Analysis on the Urgency of Environmental Cost Control of Agricultural Product Processing Industry in Jilin Province
}

\author{
Chuanlian Song \\ College of Economics \& Management, Changchun University of Science and Technology \\ Changchun, China \\ E-mail: chuanliansong@163.com
}

Received: January 10, 2011

Accepted: February 28, 2011

doi:10.5539/jsd.v4n2p260

\begin{abstract}
Jilin Province is an agricultural province and agricultural products processing industry is an important pillar industry of economic development, but because of its particularity of resource endowment such as geographical location and climate conditions, while developing agricultural products processing industry, Jilin Province must control environmental cost, in order to keep the sustainable development of agricultural products processing industry. Only considering fully the sustainability of agricultural products processing industry, its long-term development can be obtained. The article analyzes the resource situation in Jilin Province, discusses the necessity and urgency of developing agricultural products processing industry in Jilin Province.
\end{abstract}

Keywords: Jilin Province, Agricultural products processing industry, The discussion of environmental cost, Necessity, Urgency

\section{Introduction}

There are 12 industries related to agricultural products processing industry statistically in China, includes: foods processing industry, food manufacturing industry, beverage manufacturing industry, tobacco processing industry, textile industry, garment and other fibre products manufacturing industry, leather, fur, feather and their products industry, wood processing and bamboo, rattan, brown and grass products industry, furniture manufacturing industry, paper and paper products industry, printing industry, rubber products industry. There is severe environmental pollution in these types of enterprises and thus forms the environmental cost of the industrial development. In the types of enterprises, such industries as corn further-processing industry, paper-making industry, leather industry, textile industry and beverage manufacturing industry have more severe environmental pollution.

Tannery wastewater is one of important sources that pollutes water environment in China. In 20 industries whose pollution is more severe, the leather industry ranks the fifth. Using current technology, to process one ton of raw material skin every time, water consumption is $70-85 \mathrm{~m}^{3}$ and all kinds of chemical materials consumption is $600-700 \mathrm{~kg}$, what's more, about $30 \%$ of collagen from skin is discard as solid wastes, leading to resources waste while causing environmental pollution.

Paper making industry is a light industry with large output and water consumption, and severe pollution, whose water pollution ranks top in various industries. If the wastewater in paper making industry is not been disposed effectively and discharge into rivers, the organic compound in wastewater will consumes oxygen in the water so that such aquatic organism as fish and shellfish die from lack of oxygen. It's easy to cause death of fish once slender fiber suspending in water blocks gill arch. There are still some cancerogenic, teratogenic and mutagenic poisonous and harmful substances, which may pass the food chain on into human bodies and thus further do harm to people's health. According to statistics, to produce a ton of paper, wastewater discharge is about 60-220 tons, biochemical oxygen demand(BOD) is about $3.6-30 \mathrm{~kg}$, and chemical oxygen demand (COD) is about $6-135 \mathrm{~kg}$.

The industrial pollution in corn deep-processing enterprises is the pollution of water quality mainly. Because in the process of production, sulfuric acid and sulphurous acid are used to steep raw materials and hydrochloric acid and $\mathrm{NaH}_{2} \mathrm{PO}_{4}$ are also used in some technology, a great deal of acid waste water with a large number of organic matter is produced. In current situations of production, the main pollutants in waste water are COD and $\mathrm{NH}_{3}-\mathrm{N}$, and the $\mathrm{PH}$ value of water is 3-4 generally. If the waste water is discharged without disposal, water quality will lose its basic functions.

China is a country with large wine industry, with the development of social economy and improvement of people's life level, the demand of wine is increasing. The production of wine takes water as medium, and a great deal of process water and clean water are needed during brewing. The fermentation process produces various 
amino acids and protein, which are discharged with waste water and form pollution sources, cause very serious pollution to China's water environment and are one of main sources of China's water pollution.

Waste water is the foremost environmental problem in textile industry. Textile industry is one of industries with large water usage and displacement. Textile waste water mainly includes: printing and dyeing wastewater, chemical fibr production wastewater, wool washing wastewater, flax-degumming wastewater and chemical fibre pulp mill wastewater. Printing and dyeing wastewater is main pollution source in textile industry. According to incomplete statistics, daily discharge amount of waste water in China's printing and dyeing enterprises is about 3-4 million tons. Once printing and dyeing factory produces $100 \mathrm{~m}$ textile, it will produce 3-5 tons of pollution wastewater. The discharged wastewater contains matter brought by fibre raw materials, and pulp, oil, dye and chemical auxiliaries used in the processing process, which have following characteristics: 1) COD changes a lot, high to 2000-3000mg/L, BOD is also high to $2000-3000 \mathrm{mg} / \mathrm{L}$. 2) high PH value, for example, the pH of sulfur dyes and vat dyes wastewater can reach about ten; 3) large chromaticity, high content of organic matters, with a great deal of dye, auxiliaries and pulp and great viscosity in the wastewater; 4) water temperature and water yield change a lot, the changes of kinds and output of processing products cause water temperature is over $40{ }^{\circ} \mathrm{C}$ generally, and thus influence the deposal effects of wastewater.

In addition, traditional printing and dying process produce a lot of poisonous sewage. After processing some poisonous dyestuff or auxiliaries attached to the textile do harm to people's healthiness. For example, azo dye, formaldehyde, fluorescent whitening agent and softening agent have sensitization; polyvinyl alcohol and polypropylene pulp is difficultly biodegradable; the pollution of chlorine bleach is severe; some aromatic amine dyes may cause cancer; there are poisonous heavy metals; all kinds of finishing agent and textile auxiliaries with formaldehyde do harm to human bodies. If this kind of wastewater is not disposed or directly discharge without reaching stipulated emission standards, it not only does hard to people's healthiness, but also destroys water bodies, soil and ecological system seriously.

2. Low level of fiscal revenue aggravates the urgency of environmental cost control of agricultural product processing industry

Table 1 is the expenditure used in the aspect of environment protection in 2005, 2006, 2007. From the table we can see, most part of the expenditure used in environment protection and urban water resources construction in China is from local finance.

But fiscal revenue in Jilin Province is still very low currently, table 2.1, 2.2, 2.3, 3.1, 3.2, 3.3, 4.1, 4.2, 4.3 is the sequence of fiscal revenue in each province, autonomous region and municipality directly under the central government in 2005, 2006, 2007 in China respectively. Jilin Province ranks 24.

This shows, if Jilin Province doesn't control its environmental pollution, with national concern about people's life and its importance to the environmental problems, related governing laws will come on gradually. Until then, Jilin Province still has to spend a lot of financial resources on restoring and managing environment, invested fiscal revenue may be larger than current control cost, even exceeds the limit that the government can endure.

\section{The advantages of Jilin Province as main grain-producing area aggravates the urgency of} environmental cost control of agricultural product processing industry

Jilin Province is an agricultural province with fertile soil, particularly suitable for the plants such as grain bean, oil-bearing crop, beet, tobacco, potato, ginseng, medicine and fruits. The planting area is 395.9 million hectares, rich in corn, soybeans, rice. Commissariat of average per capita, food goods rate, the volume of exports of food, corn export volume list on the top two for several years. (Table 5.1, 5.2 are the sequences of commissariat of average per capita in 2007 in China)

Long-term backward economy makes the desire of Jilin Province to develop agricultural product processing industry more urgent. Therefore, in the industry planning, Jilin Province fixes agricultural product processing industry as the third pillar industry inferior to automobile and petroleum, which decides the pollution contribution value of agricultural product processing industry in Jilin Province is higher than other provinces inevitably.

\section{Vulnerable resource endowment becomes the constraint factors of the development of agricultural} product processing industry in Jilin Province

\subsection{Jilin Province is short of water and its distribution is uneven}

\subsubsection{Jilin Province is very short of water}

Agricultural product processing industry mainly causes water pollution, but from the resource endowment of Jilin province we can see it's an area very short of water. According to China Statistical Yearbook in 2008, the water resources in total amount in 2007 in Jilin Province is 34.6 billion cubic meters, the amount of surface water resource is 30.15 billion cubic meters, the amount of groundwater is 8.63 billion cubic meters, and the amount of surface water and groundwater replication is 4.78 billion cubic meters, but average of water per capita is only 1269 cubic meters/per, accounting for $66.22 \%$ of national average water 1916.3 cubic meters/per, which 
belongs to a province very short of water.

From the results of analysis of table 6.1, 6.2, 7.1 and 7.2 we can see the total amount of water resource in Jilin Province ranks 21 in 31 provinces, autonomous regions and municipalities, the amount of water per capita ranks 17 , which belongs to a province short of water in the country short of water, very short of water resource.

4.1.2 Uneven distribution of water resources aggravates the situation short of water in Jilin Province

From the distribution of water resources in Jilin Province, the eastern area has much water but little land, the middle area has little water but much land, and the western area has more wind and sand, is dry, very short of water. There's the phenomenon of uneven distribution of water resources, characteristiced by structural shortage of water. From administrative districts we can see the water resource in each district is also uneven in Jilin province. Table 8 is water resource evaluation form of each district in Jilin Province, showing the middle area of Jilin Province is very short of water.

The middle are of Jilin is just the important producing field of agricultural products and agricultural product processing industry get together here. Comparatively speaking, the water in the area is much poor. It's necessary to implement environmental cost control for development.

\subsection{The climate condition of Jilin is not conductive to the self-purification of contaminated water}

From the climate condition, Jilin Province is located in the middle of northeastern China, and is in the northern temperate monsoon region. Its geographic coordinate is between east longitude $121^{\circ} 38^{\prime}-131^{\circ} 19^{\prime}$ and northern latitude $40^{\circ} 52^{\prime}-46^{\circ} 18^{\circ}$. The climate is located in low temperate continental monsoon climate zone, with four distinct seasons, hot rainy season, and obvious alternations of four seasons. Spring, dry and windy; summer, heat and rainy; winter, cold and long; the icy season of rivers can reach 4-5 months, when the runoff generally accounts for 5\%-10\% of annual runoff. Generally from the end of January to February annually, the largest ice thickness and smallest runoff appear, when is called the low water period of rivers. From May to the first ten days of June annually, cold high pressure moves northward while rainy season has not come, the rivers come into medium season again. The environmental degradation and self-purification capacity during annual period of icy season and medium season are very low.

\section{Conclusions}

Through the analysis above we can see, environmental cost control of agricultural product processing industry in Jilin province is especially necessary compared with southern area. If the problem of out of control in environmental cost is not solved, it's will influence the sustainable development of agricultural product processing industry in Jilin province inevitably.

\section{References}

Ji, Tan. (2007). The NDRC imposes restrictions on foreign investment in maize in-depth processing industry. [Online]: available: http://www.sina.com.cn. September 21, 2007.

Jia, Tianxi. (2006). Understandings about several problems about environment cost. Shan Xi Finance and Tax. 2006, 12.

Ning, Jing. (2007). Current situations about Green GDP accounting in China. Co-operative economy and science. 2007,4 .

Sun, Xinghua. (2004). GREEN ECONOMY CALLS FOR GREEN AUDIT SUPERVISION. Green China. 2004, 23.

Wang, Yaotang \& Zhao, Ziye. (2002). Management of Environment Costs: pre-programming Methods and its Enlightenment. ACCOUNTING RESEARCH. 2002, 1.

Table 1. Expenditure used in environment protection and urban water resources construction in 2005, 2006, 2007 in China (billion yuan)

\begin{tabular}{|l|l|l|l|}
\hline & & From local finance & From state finance \\
\hline 2005 & 132.97 & 132.97 & 0 \\
\hline 2006 & 161.24 & 161.24 & 0 \\
\hline 2007 & 995.82 & 180.14 & 14.21 \\
\hline
\end{tabular}

Data source: China Statistical Yearbook in 2006, 2007, 2008 
Table 2.1 the sequence of fiscal revenue in each province, autonomous region and municipality directly under the central government in 2005 (million yuan)

\begin{tabular}{|l|l|l|l|l|l|l|l|l|l|l|}
\hline 1 & 2 & 3 & 4 & 5 & 6 & 7 & 8 & 9 & 10 & 11 \\
\hline Guangdong & Shanghai & Jiangsu & Shandong & Zhejiang & Beijing & Liaoning & Henan & Hebei & Sichuan & Fujian \\
\hline 18072044 & 14173976 & 13226753 & 10731250 & 10665964 & 9192098 & 6752768 & 5376514 & 5157017 & 4796635 & 4326003 \\
\hline
\end{tabular}

Table 2.2 the sequence of fiscal revenue in each province, autonomous region and municipality directly under the central government in 2005 (million yuan)

\begin{tabular}{|l|l|l|l|l|l|l|l|l|l|l|}
\hline 12 & 13 & 14 & 15 & 16 & 17 & 18 & 19 & 20 & 21 & 22 \\
\hline Hunan & Hubei & Shanxi & Anhui & Tianjin & Heilongjiang & Yunnan & Guangxi & $\begin{array}{l}\text { Inner } \\
\text { Mongolia }\end{array}$ & Shaanxi & Chongqing \\
\hline 3952651 & 3755217 & 3683437 & 3340170 & 3318507 & 3182056 & 3126490 & 2830359 & 2774553 & 2753183 & 2568072 \\
\hline
\end{tabular}

Table 2.3 the sequence of fiscal revenue in each province, autonomous region and municipality directly under the central government in 2005 (million yuan)

\begin{tabular}{|l|l|l|l|l|l|l|l|l|}
\hline 23 & 24 & 25 & 26 & 27 & 28 & 29 & 30 & 31 \\
\hline Jiangxi & Jilin & Guizhou & Xinjiang & Gansu & Hainan & Ningxia & Qinghai & Xizang \\
\hline 2529236 & 2071520 & 1824963 & 1803184 & 1235026 & 686802 & 477216 & 338222 & 120312 \\
\hline
\end{tabular}

Data source: China Statistical Yearbook in 2006, 2007, 2008

Table 3.1 the sequence of fiscal revenue in each province, autonomous region and municipality directly under the central government in 2006 (million yuan)

\begin{tabular}{|l|l|l|l|l|l|l|l|l|l|l|}
\hline 1 & 2 & 3 & 4 & 5 & 6 & 7 & 8 & 9 & 10 & 11 \\
\hline Guangdong & Jiangsu & Shanghai & Shandong & Zhejiang & Beijing & Liaoning & Henan & Hebei & Sichuan & Shanxi \\
\hline 21794608 & 16566820 & 15760742 & 13562526 & 12982044 & 11171514 & 8186718 & 6791715 & 6205340 & 6075850 & 5833752 \\
\hline
\end{tabular}

Table 3.2 the sequence of fiscal revenue in each province, autonomous region and municipality directly under the central government in 2006 (million yuan)

\begin{tabular}{|l|l|l|l|l|l|l|l|l|l|l|}
\hline 12 & 13 & 14 & 15 & 16 & 17 & 18 & 19 & 20 & 21 & 22 \\
\hline Fujian & Hunan & Hubei & Anhui & Tianjin & Heilongjiang & Yunnan & Shaanxi & $\begin{array}{l}\text { Inner } \\
\text { Mongolia }\end{array}$ & Guangxi & Chongqing \\
\hline 5411707 & 4779274 & 4760823 & 4280265 & 4170479 & 3868440 & 3799702 & 3624805 & 3433774 & 3425788 & 317165 \\
\hline
\end{tabular}

Table 3.3 the sequence of fiscal revenue in each province, autonomous region and municipality directly under the central government in 2006 (million yuan)

\begin{tabular}{|l|l|l|l|l|l|l|l|l|}
\hline 23 & 24 & 25 & 26 & 27 & 28 & 29 & 30 & 31 \\
\hline Jiangxi & Jilin & Guizhou & Xinjiang & Gansu & Hainan & Ningxia & Qinghai & Xizang \\
\hline 3055214 & 2452045 & 2268157 & 2194628 & 1412152 & 818139 & 613570 & 422437 & 145607 \\
\hline
\end{tabular}

Data source: China Statistical Yearbook in 2006, 2007, 2008

Table 4.1 the sequence of fiscal revenue in each province, autonomous region and municipality directly under the central government in 2007 (million yuan)

\begin{tabular}{|l|l|l|l|l|l|l|l|l|l|l|}
\hline 1 & 2 & 3 & 4 & 5 & 6 & 7 & 8 & 9 & 10 & 11 \\
\hline Guangdong & Shanghai & Jiangsu & Zhejiang & Beijing & Shandong & Liaoning & Sichuan & Henan & Hebei & Fujian \\
\hline 24154724 & 19754796 & 18947700 & 15353548 & 14356708 & 13083516 & 8156685 & 6289529 & 6250156 & 6182963 & 5940236 \\
\hline
\end{tabular}


Table 4.2 the sequence of fiscal revenue in each province, autonomous region and municipality directly under the central government in 2007 (million yuan)

\begin{tabular}{|l|l|l|l|l|l|l|l|l|l|l|}
\hline 12 & 13 & 14 & 15 & 16 & 17 & 18 & 19 & 20 & 21 & 22 \\
\hline Tianjin & Hubei & Shanxi & Hunan & Anhui & Yunnan & Shaanxi & $\begin{array}{l}\text { Inner } \\
\text { Mongolia }\end{array}$ & Heilongjiang & Chongqing & Guangxi \\
\hline 4383644 & 4339759 & 4305002 & 4106600 & 4018799 & 3786361 & 3555047 & 3479057 & 3349661 & 2944592 & 2826809 \\
\hline
\end{tabular}

Table 4.3 the sequence of fiscal revenue in each province, autonomous region and municipality directly under the central government in 2007 (million yuan)

\begin{tabular}{|l|l|l|l|l|l|l|l|l|}
\hline 23 & 24 & 25 & 26 & 27 & 28 & 29 & 30 & 31 \\
\hline Jiangxi & Jilin & Xinjiang & Guizhou & Gansu & Hainan & Ningxia & Qinghai & Xizang \\
\hline 2818573 & 2373862 & 2206460 & 2118512 & 1420532 & 879935 & 585871 & 432855 & 116667 \\
\hline
\end{tabular}

Data source: China Statistical Yearbook in 2006, 2007, 2008

Table 5.1 the sequences of commissariat of average per capita in each province, autonomous region and municipality directly under the central government and national average commissariat in 2007 in China $(\mathrm{Kg})$

\begin{tabular}{|l|l|l|l|l|l|l|l|l|l|l|l|l|l|l|l|}
\hline 1 & 2 & 3 & 4 & 5 & 6 & 7 & 8 & 9 & 10 & 11 & 12 & 13 & 14 & 15 & 16 \\
\hline $\begin{array}{l}\text { Heilo } \\
\text { ngjian } \\
\text { g }\end{array}$ & Jilin & $\begin{array}{l}\text { Inner } \\
\text { Mon } \\
\text { goli } \\
\text { a }\end{array}$ & $\begin{array}{l}\text { He } \\
\text { nan }\end{array}$ & $\begin{array}{l}\text { Ning } \\
\text { xia }\end{array}$ & $\begin{array}{l}\text { An } \\
\text { hui }\end{array}$ & $\begin{array}{l}\text { Shand } \\
\text { ong }\end{array}$ & $\begin{array}{l}\text { Jian } \\
\text { gxi }\end{array}$ & $\begin{array}{l}\text { Liao } \\
\text { ning }\end{array}$ & $\begin{array}{l}\text { Hu } \\
\text { nan }\end{array}$ & $\begin{array}{l}\text { Xinji } \\
\text { ang }\end{array}$ & $\begin{array}{l}\text { Jian } \\
\text { gsu }\end{array}$ & $\begin{array}{l}\text { He } \\
\text { bei }\end{array}$ & $\begin{array}{l}\text { Chong } \\
\text { qing }\end{array}$ & $\begin{array}{l}\text { Hu } \\
\text { bei }\end{array}$ & $\begin{array}{l}\text { Nati } \\
\text { on } \\
\text { aver } \\
\text { age }\end{array}$ \\
\hline 906 & 900 & 754 & 559 & 533 & 475 & 444 & 437 & 428 & 424 & 418 & 413 & 411 & 387 & 384 & 381 \\
\hline
\end{tabular}

Table 5.2 the sequences of commissariat of average per capita in each province, autonomous region and municipality directly under the central government and national average commissariat in 2007 in China $(\mathrm{Kg})$

\begin{tabular}{|l|l|l|l|l|l|l|l|l|l|l|l|l|l|l|l|}
\hline 17 & 18 & 19 & 20 & 21 & 22 & 23 & 24 & 25 & 26 & 27 & 28 & 29 & 30 & 31 & 32 \\
\hline $\begin{array}{l}\text { Sich } \\
\text { uan }\end{array}$ & $\begin{array}{l}\text { Xiz } \\
\text { ang }\end{array}$ & $\begin{array}{l}\text { Yun } \\
\text { nan }\end{array}$ & $\begin{array}{l}\text { Ga } \\
\text { nsu }\end{array}$ & $\begin{array}{l}\text { Sha } \\
\text { nxi }\end{array}$ & $\begin{array}{l}\text { Guan } \\
\text { gxi }\end{array}$ & $\begin{array}{l}\text { Guiz } \\
\text { hou }\end{array}$ & $\begin{array}{l}\text { Shaa } \\
\text { nxi }\end{array}$ & $\begin{array}{l}\text { Hai } \\
\text { nan }\end{array}$ & $\begin{array}{l}\text { Qing } \\
\text { hai }\end{array}$ & $\begin{array}{l}\text { Fuji } \\
\text { an }\end{array}$ & $\begin{array}{l}\text { Zheji } \\
\text { ang }\end{array}$ & $\begin{array}{l}\text { Guang } \\
\text { dong }\end{array}$ & $\begin{array}{l}\text { Tian } \\
\text { jin }\end{array}$ & $\begin{array}{l}\text { Beij } \\
\text { ing }\end{array}$ & $\begin{array}{l}\text { Shan } \\
\text { ghai }\end{array}$ \\
\hline 372 & 332 & 325 & 316 & 298 & 294 & 293 & 285 & 211 & 193 & 178 & 145 & 137 & 134 & 64 & 59 \\
\hline
\end{tabular}

Data source: China Statistical Yearbook in 2006, 2007, 2008

Table 6.1 The sequence of the water resources in total amount of each province, autonomous region and municipality directly under the central government in 2007(a hundred million cubic meters)

\begin{tabular}{|l|l|l|l|l|l|l|l|l|l|l|l|l|l|l|l|}
\hline 1 & 2 & 3 & 4 & 5 & 6 & 7 & 8 & 9 & 10 & 11 & 12 & 13 & 14 & 15 & 16 \\
\hline $\begin{array}{l}\text { Xiza } \\
\text { ng }\end{array}$ & $\begin{array}{l}\text { Sich } \\
\text { uan }\end{array}$ & $\begin{array}{l}\text { Yun } \\
\text { nan }\end{array}$ & $\begin{array}{l}\text { Guang } \\
\text { dong }\end{array}$ & $\begin{array}{l}\text { Hun } \\
\text { an }\end{array}$ & $\begin{array}{l}\text { Guan } \\
\text { gxi }\end{array}$ & $\begin{array}{l}\text { Jian } \\
\text { gxi }\end{array}$ & $\begin{array}{l}\text { Fuji } \\
\text { an }\end{array}$ & $\begin{array}{l}\text { Guiz } \\
\text { hou }\end{array}$ & $\begin{array}{l}\text { Hu } \\
\text { bei }\end{array}$ & $\begin{array}{l}\text { Zheji } \\
\text { ang }\end{array}$ & $\begin{array}{l}\text { Xinji } \\
\text { ang }\end{array}$ & $\begin{array}{l}\text { An } \\
\text { hui }\end{array}$ & $\begin{array}{l}\text { Chong } \\
\text { qing }\end{array}$ & $\begin{array}{l}\text { Qing } \\
\text { hai }\end{array}$ & $\begin{array}{l}\text { Jian } \\
\text { gsu }\end{array}$ \\
\hline 4214 & 2998 & 2255 & 15812 & 14265 & 13863 & 1113 & 10729 & 10546 & 10151 & 8921 & 8638 & 7125 & 663 & 6616 & 4957 \\
\hline
\end{tabular}

Table 6.2 The sequence of the water resources in total amount of each province, autonomous region and municipality directly under the central government in 2007(a hundred million cubic meters)

\begin{tabular}{|l|l|l|l|l|l|l|l|l|l|l|l|l|l|l|}
\hline 17 & 18 & 19 & 20 & 21 & 22 & 23 & 24 & 25 & 26 & 27 & 28 & 29 & 30 & 31 \\
\hline $\begin{array}{l}\text { Heilongj } \\
\text { iang }\end{array}$ & $\begin{array}{l}\text { Hen } \\
\text { an }\end{array}$ & $\begin{array}{l}\text { Shand } \\
\text { ong }\end{array}$ & $\begin{array}{l}\text { Shaa } \\
\text { nxi }\end{array}$ & $\begin{array}{l}\text { Jil } \\
\text { in }\end{array}$ & $\begin{array}{l}\text { Inner } \\
\text { Mong } \\
\text { lia }\end{array}$ & $\begin{array}{l}\text { Hain } \\
\text { an }\end{array}$ & $\begin{array}{l}\text { Liaon } \\
\text { ing }\end{array}$ & $\begin{array}{l}\text { Gan } \\
\text { su }\end{array}$ & $\begin{array}{l}\text { Heb } \\
\text { ei }\end{array}$ & $\begin{array}{l}\text { Sha } \\
\text { nxi }\end{array}$ & $\begin{array}{l}\text { Shang } \\
\text { hai }\end{array}$ & $\begin{array}{l}\text { Beiji } \\
\text { ng }\end{array}$ & $\begin{array}{l}\text { Tian } \\
\text { jin }\end{array}$ & $\begin{array}{l}\text { Ning } \\
\text { xia }\end{array}$ \\
\hline 491.8 & 4652 & 387.1 & 37 & 346 & 2959 & 2835 & 261.7 & 228.7 & 119.8 & 103.4 & 345 & 23.8 & 113 & 10.4 \\
\hline
\end{tabular}

Data source: China Statistical Yearbook in 2006, 2007, 2008 
Table 7.1 the sequence of the amount of water per capita in each province, autonomous region and municipality directly under the central government in 2007(cubic meters/per)

\begin{tabular}{|c|c|c|c|c|c|c|c|c|c|c|c|c|c|c|c|}
\hline 1 & 2 & 3 & 4 & 5 & 6 & 7 & 8 & 9 & 10 & 11 & 12 & 13 & 14 & 15 & 16 \\
\hline $\begin{array}{l}\text { Xiz } \\
\text { ang }\end{array}$ & $\begin{array}{l}\text { Qing } \\
\text { hai }\end{array}$ & $\begin{array}{l}\text { Yun } \\
\text { nan }\end{array}$ & $\begin{array}{l}\text { Xinji } \\
\text { ang }\end{array}$ & $\begin{array}{l}\text { Hai } \\
\text { nan }\end{array}$ & $\begin{array}{l}\text { Fuji } \\
\text { an }\end{array}$ & $\begin{array}{l}\text { Guan } \\
\text { gxi }\end{array}$ & $\begin{array}{l}\text { Sich } \\
\text { uan }\end{array}$ & $\begin{array}{l}\text { Guiz } \\
\text { hou }\end{array}$ & $\begin{array}{l}\text { Jian } \\
\text { gxi }\end{array}$ & $\begin{array}{l}\text { Chong } \\
\text { qing }\end{array}$ & $\begin{array}{l}\mathrm{Hu} \\
\text { nan }\end{array}$ & $\begin{array}{l}\mathrm{Hu} \\
\text { bei }\end{array}$ & $\begin{array}{l}\text { Zheji } \\
\text { ang }\end{array}$ & $\begin{array}{l}\text { Guang } \\
\text { dong }\end{array}$ & $\begin{array}{l}\text { Heilong } \\
\text { jiang }\end{array}$ \\
\hline 152992 & 2025 & 50139 & 4168 & 3373 & 3087 & 2024 & 2826 & 2802 & 2556 & 2556 & 247.1 & 17821 & $17 \pi 2$ & 1683 & 284 \\
\hline
\end{tabular}

Table 7.2 the sequence of the amount of water per capita in each province, autonomous region and municipality directly under the central government in 2007 (cubic meters/per)

\begin{tabular}{|l|l|l|l|l|l|l|l|l|l|l|l|l|l|l|}
\hline 17 & 18 & 19 & 20 & 21 & 22 & 23 & 24 & 25 & 26 & 27 & 28 & 29 & 30 & 31 \\
\hline Jilin & $\begin{array}{l}\text { Inner } \\
\text { Mong } \\
\text { olia }\end{array}$ & $\begin{array}{l}\text { Anh } \\
\text { ui }\end{array}$ & $\begin{array}{l}\text { Shaan } \\
\text { xi }\end{array}$ & $\begin{array}{l}\text { Gan } \\
\text { su }\end{array}$ & $\begin{array}{l}\text { Jiang } \\
\text { su }\end{array}$ & $\begin{array}{l}\text { Liaoni } \\
\text { ng }\end{array}$ & $\begin{array}{l}\text { Hen } \\
\text { an }\end{array}$ & $\begin{array}{l}\text { Shando } \\
\text { ng }\end{array}$ & $\begin{array}{l}\text { Shan } \\
\text { xi }\end{array}$ & $\begin{array}{l}\text { Shang } \\
\text { hai }\end{array}$ & $\begin{array}{l}\text { Heb } \\
\text { ei }\end{array}$ & $\begin{array}{l}\text { Ningx } \\
\text { ia }\end{array}$ & $\begin{array}{l}\text { Beiji } \\
\text { ng }\end{array}$ & $\begin{array}{l}\text { Tianj } \\
\text { in }\end{array}$ \\
\hline 12992 & 12322 & 11652 & 1007.7 & 858 & 6533 & 6108 & 4961 & 446 & 3066 & 1875 & 173.1 & 17.1 & 1482 & 1033 \\
\hline
\end{tabular}

Data source: China Statistical Yearbook in 2006, 2007, 2008

Table 8. Water resource evaluation form of each district in Jilin Province

\begin{tabular}{|c|c|c|c|c|c|}
\hline district & $\begin{array}{l}\text { Land } \\
\text { area }\left(\mathrm{km}^{2}\right)\end{array}$ & $\begin{array}{l}\begin{array}{l}\text { The total amount of } \\
\text { water(one } \\
\text { cubic meters ) }\end{array} \\
\end{array}$ & $\begin{array}{l}\text { Population in } \\
\text { 2003(thousand) }\end{array}$ & $\begin{array}{l}\text { The amount of } \\
\text { water per capita } \\
\left(\mathrm{m}^{3}\right)\end{array}$ & $\begin{array}{l}\text { Degree of water } \\
\text { shortage }\end{array}$ \\
\hline Changchun & 18881 & 27.46 & 742 & 370 & $\begin{array}{ll}\text { extreme } & \text { water } \\
\text { shortage } & \end{array}$ \\
\hline Jilin & 27100 & 70.58 & 451.4 & 1564 & $\begin{array}{l}\text { Moderate water } \\
\text { shortage }\end{array}$ \\
\hline Siping & 14037 & 16.45 & 326.7 & 504 & $\begin{array}{ll}\begin{array}{l}\text { Serious } \\
\text { shortage }\end{array} & \text { water } \\
\end{array}$ \\
\hline Liaoyuan & 5130 & 7.63 & 126 & 606 & $\begin{array}{ll}\begin{array}{l}\text { Serious } \\
\text { shortage }\end{array} & \text { water } \\
\end{array}$ \\
\hline Tonghua & 15100 & 55.30 & 226.2 & 2445 & $\begin{array}{ll}\begin{array}{l}\text { Light } \\
\text { shortage }\end{array} & \text { water } \\
\end{array}$ \\
\hline Baishan & 17852 & 71.51 & 133.2 & 5369 & \\
\hline Songyuan & 21000 & 13.83 & 279.4 & 495 & $\begin{array}{ll}\text { extreme } & \text { water } \\
\text { shortage } & \end{array}$ \\
\hline Baicheng & 25600 & 20.09 & 204.1 & 984 & $\begin{array}{ll}\begin{array}{l}\text { Serious } \\
\text { shortage }\end{array} & \text { water } \\
\end{array}$ \\
\hline Yanbian & 42700 & 115.98 & 218.6 & 5306 & \\
\hline Total & 187400 & 398.83 & 2707.6 & 1473 & $\begin{array}{l}\text { Moderate water } \\
\text { shortage }\end{array}$ \\
\hline
\end{tabular}

Note: International water shortage standards: according to the amount of water per capita, 2000-3000 cubic meters is light water shortage, 1000-2000 cubic meters is moderate water shortage, 500-1000 cubic meters is serious water shortage; less than 500 cubic meters is extreme water shortage.

Data source: municipal urban system planning of Jilin Province (2005-2020) edited by the editorial board of Local chronicles in Jilin Province, Jilin People Press, October 2005. 